\title{
Ash pollen season in Poland in 2019
}

\author{
Małgorzata Puc ${ }^{1,2}$, Daniel Kotrych ${ }^{3}$, Agnieszka Lipiec ${ }^{4}$, Kazimiera Chłopek ${ }^{5}$, Dariusz Jurkiewicz \\ Ewa Kalinowska ${ }^{7}$, Krystyna Piotrowska-Weryszko ${ }^{8}$, Piotr Rapiejko, ${ }^{6,7}$, Zenon Siergiejko ${ }^{9}$ \\ ${ }^{1}$ Institute of Marine \& Environmental Sciences, University of Szczecin, Poland \\ ${ }^{2}$ Molecular Biology and Biotechnology Centre, Faculty of Biology, University of Szczecin, Poland \\ ${ }^{3}$ Department of Orthopedics and Traumatology, Pomeranian Medical University of Szczecin, Poland \\ ${ }^{4}$ Department of Prevention of Environmental Hazards and Allergology, Medical University of Warsaw, Poland \\ ${ }^{5}$ Faculty of Natural Sciences, Institute of Earth Sciences, University of Silesia in Katowice, Poland \\ ${ }^{6}$ Department of Otolaryngology with Division of Cranio-Maxillo-Facial Surgery in Military Institute of Medicine, \\ Warsaw, Poland \\ Allergen Research Center, Warsaw, Poland \\ ${ }^{8}$ Department of Botany and Plant Physiology, University of Life Sciences in Lublin, Poland \\ ${ }^{9}$ Laboratory of Respiratory Diagnostics and Bronchoscopy, Medical University of Bialystok, Poland
}

\begin{abstract}
:
Pollen grains are one of the most important groups of atmospheric biological particles that cause allergic processes. Meteorological factors affect the occurrence of pollen allergen release in the air. In order to shed light on this phenomenon this study compares the ash pollen seasons in Bialystok, Bydgoszcz, Sosnowiec, Piotrkow Trybunalski, Opole, Olsztyn, Szczecin, Warsaw and Lublin in 2019. The investigations were carried out using the volumetric method (Hirst type pollen sampler). Seasonal Pollen Index (SPI) was estimated as the sum of daily average pollen concentrations in the given season. The ash pollination is mainly observed in April. Diagnosis of ash pollen allergy is made difficult due to an overlapping pollination period with Betulaceae and some cross-reactivity with allergens from Betulaceae. It is not clear whether ash pollen is a primary cause of sensitization or whether it is implicated through cross-sensitization to other pollens. In 2019 the pollen season of ash started first in Opole, on the March $9^{\text {th }}$. At the latest, a pollen season ended in Bialystok, after mid may. The differences of pollen seasons duration were very considerable, from 28 to 50 days. The highest airborne concentration of 190 pollen grains $/ \mathrm{m}^{3}$ was noted in Lublin on the April $21^{\text {st }}$. The maximum values of seasonal pollen count in Polish cities occurred between April $4^{\text {th }}$ and $22^{\text {nd }}$, most often between April $18^{\text {th }}-22^{\text {nd }}$. The highest ash pollen allergen hazard occurred in 2019 in Lublin, Warsaw, Piotrkow Trybunalski and Bydgoszcz, and was at least three times higher than in other cities. The highest variability in the analysed seasons was found in the peak value and annual total.
\end{abstract}

Key words: aeroallergens, pollen count, ash (Fraxinus excelsior), 2019

$\mathrm{n}$ temperate zones of North-Central Europe the sensitization to ash pollen is a recognized problem, also extended to the Northern areas of the Mediterranean basin. Some observations in Poland suggest that ash pollen season could be as important as birch pollen period due to cross-reactions. The allergenic significance of this pollen has been poorly studied in Europe as the amounts of ash pollen are low [1].

Fraxinus genus belongs to the Oleales Lindl. order and the Oleaceae Hoffmanns and Link family, which also includes Forsythia, Ligustrum, Jasminum and Syringa [2]. Ash is a species occurring in Europe and also in Asia Minor. In the north it reaches central Sweden and northern Finland, and in the south it reaches just the northern edge of the Iberian Peninsula, but occurs over much of the Apennine Peninsula and the Balkans. In the European sub-Mediterranean regions ash is found only in the cool and moist montane zones [3].

Within the present-day borders of Poland, only Fraxinus excelsior is found; this genus is quite regularly distributed throughout the country. In the 
mountains, it rarely occurs at altitudes over $800 \mathrm{~m}$. It prefers the warm temperature climate of the European sub-oceanic area and it has a varied and quite wide tolerance of hydrological conditions, soil type and light conditions. Ash is wind-pollinated and begins to flower in April and continues to flower almost until the end of May. Fraxinus excelsior can develop male, female and hermaphrodite flowers. Its pollen production is rather low, up to 160,000 pollen grains in an inflorescence. Knowledge of intradiurnal variation patterns and meteorological influence is important for allergy patients and permits avoiding overexposure to allergens, therefore this should be taken into account when planning outdoor activities. Birch pollen is the most important agent causing pollinosis in Europe while ash pollen is rarely its cause, but the allergens of the pollen of Betula and Fraxinus show the cross-reactivity (an interaction between an antibody and an antigen closely related to the antigen that specifically stimulated synthesis of the antibody), which can enhance the allergy symptoms in persons allergic to the pollen of one of these taxa. Ash pollen allergens are also cross-reactive with Timothy grass and Olive pollen. Pollinosis and allergic respiratory disorders of a population in a given geographical region are mainly determined by the presence and quantity of native plants causing allergy. Weather parameters are known to affect the dispersion dynamics of particles of biological origin. The release and dispersal of pollen also depend on the microclimate, which explains the differences in the timing of flowering and occurrence of pollen in the air for the same species [4]. Increasing concentrations of atmospheric pollutants, i.e. carbon oxides, sulphur dioxide, nitrogen oxides and particulate matter (PM) in industrialized regions and urban complexes intensify the risk of allergies. Subjects living in urban areas tend to be more affected by plant-derived respiratory disorders than those who live in rural areas. Separate effects of bioaerosols and gaseous air pollutions, as well as their synergistic effects, can aggravate respiratory allergy and other pulmonary diseases. Moreover, $\mathrm{NO}_{2}$ and $\mathrm{SO}_{2}$ can modify the structure of allergens [5]

Aim

The aim of the study was to compare the ash pollen concentrations in the air of Bialystok, Bydgoszcz, Sosnowiec, Piotrkow Trybunalski, Opole, Olsztyn, Szczecin, Warsaw and Lublin in 2019 as well as to indicate the highest risk of pollen allergens in individual cities.

\section{Material and method}

Measurements of aeroplankton were carried out in the selected cities of Poland, in Bialystok, Bydgoszcz, Sosnowiec, Piotrkow Trybunalski, Opole, Olsztyn, Szczecin, Warsaw and Lublin in 2019. Measurements were performed by the volumetric method. The used devices, which are recommended by the IAA (International Association for Aerobiology), take air samples (Burkard and Lanzoni as the Hirst type pollen sampler) in volumes corresponding to average human respiratory parameters [6].

The duration of the pollen season was determined by the $98 \%$ method [7], assuming that the onset and end of the season were days with recorded $1 \%$ and $99 \%$ of the annual total of pollen grains, respectively. The total pollen count over this period was expressed by the SPI (Seasonal Pollen Index).

On the basis of literature data, the number of days was determined in which concentrations of pollen of the Fraxinus genus exceed the threshold values of consecutive allergy symptoms' development (tab. 1) [8, 9].

\section{Results and discussion}

European ash (Fraxinus excelsior) is a common cause of asthma, allergic rhinitis and allergic conjunctivitis in particular in Central and Northern Europe, as has been recognised in recent years. The tree is regarded as contributing to important health problems. In patients living near Strasbourg, ash pollen induces nearly $4 \%$ of the total sensitisation of the allergic population [10].

In central Europe the main pollen season of Fraxinus largely overlaps with the Betula pollination season. Birch pollen causes allergy in a substantial part of pollen-sensitive people in Poland (ca. 15\%). Research also confirms that there is a risk of cross-reactions between Betula and Fraxinus pollen allergens. Patients allergic to alder and hazel pollen are also frequently sensitized to Fraxinus pollen. However, the risk of allergy to Fraxinus is still scarcely reported [11]. In south Europe Oleaceae (olive family) pollen allergy is common. Allergy to ash pollen, for example, is well known in Switzerland [1]. In Poland, ash and birch pollination periods usually coincide with each other in April and pollen allergen exposure during this period is the highest.

In 2019 ash pollen season started between March $9^{\text {th }}$ in Opole and April $3^{\text {rd }}$ in Piotrkow Trybunalski and lasted until the turn of April/May (until May $19^{\text {th }}$ in Bialystok). While in 2017 the Fraxinus pollen season in most Polish cities started the earliest 
Table 1. Characteristics of yew and juniper pollen season in 2019.

\begin{tabular}{|c|c|c|c|c|c|c|c|c|c|}
\hline $\begin{array}{l}\text { Features of pollen } \\
\text { season/city }\end{array}$ & Bialystok & Bydgoszez & Sosnowiec & Lublin & Olsztyn & Opole & $\begin{array}{l}\text { Piotrkow } \\
\text { Trybunalski }\end{array}$ & Szczecin & Warsaw \\
\hline $\begin{array}{l}\text { Duration of pollen season } \\
\text { (number of days) }\end{array}$ & $\begin{array}{c}31 \mathrm{III-} \\
19 \mathrm{~V} \\
(50)\end{array}$ & $\begin{array}{c}22 \text { III- } \\
29 \text { IV } \\
(39)\end{array}$ & $\begin{array}{c}21 \text { III-2 V } \\
(43)\end{array}$ & $\begin{array}{c}30 \mathrm{III-} \\
28 \mathrm{IV} \\
(30)\end{array}$ & $\begin{array}{l}2 \text { IV- } \\
7 \mathrm{~V} \\
(36)\end{array}$ & $\begin{array}{c}9 \text { III-27 IV } \\
(50)\end{array}$ & $\begin{array}{c}3 \text { IV-3 V } \\
(31)\end{array}$ & $\begin{array}{c}29 \text { III- } \\
25 \text { IV } \\
(28)\end{array}$ & $\begin{array}{c}2 \text { IV-30 IV } \\
(29)\end{array}$ \\
\hline $\begin{array}{l}\text { Seasonal Pollen Index SPI } \\
\text { (total) }\end{array}$ & 285 & 1556 & 557 & 2207 & 766 & 718 & 1752 & 1151 & 1738 \\
\hline Peak value and peak date & $\begin{array}{c}44 \\
(18 \mathrm{IV})\end{array}$ & $\begin{array}{c}138 \\
(22 \mathrm{IV})\end{array}$ & $\begin{array}{c}48 \\
(9 \mathrm{IV})\end{array}$ & $\begin{array}{c}190 \\
(21 \mathrm{IV})\end{array}$ & $\begin{array}{c}79 \\
(20 \mathrm{IV})\end{array}$ & $\begin{array}{c}57 \\
(6 \mathrm{IV})\end{array}$ & $\begin{array}{c}165 \\
(22 \mathrm{IV})\end{array}$ & $\begin{array}{l}131 \\
(4 \mathrm{IV})\end{array}$ & $\begin{array}{c}178 \\
(22 \mathrm{IV})\end{array}$ \\
\hline Days $\geq 45$ grains $/ m^{3}[9]$ & 1 & 14 & 4 & 18 & 6 & 5 & 17 & 8 & 18 \\
\hline Days $\geq 85$ grains $/ \mathrm{m}^{3}[9]$ & 0 & 7 & 0 & 13 & 0 & 0 & 8 & 4 & 7 \\
\hline Days $\geq 150$ grains $/ \mathrm{m}^{3}[8]$ & 0 & 0 & 0 & 5 & 0 & 0 & 2 & 0 & 1 \\
\hline
\end{tabular}

Figure 1. Ash pollen count in Bialystok and Bydgoszcz in 2019.

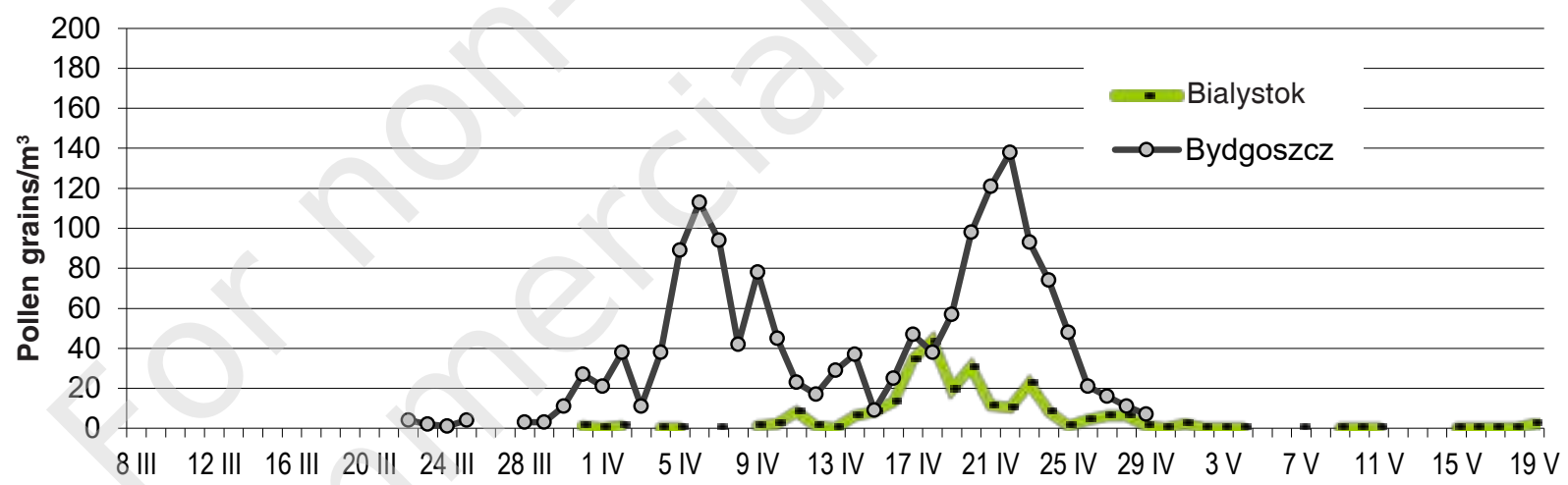

Figure 2. Ash pollen count in Sosnowiec and Lublin in 2019.

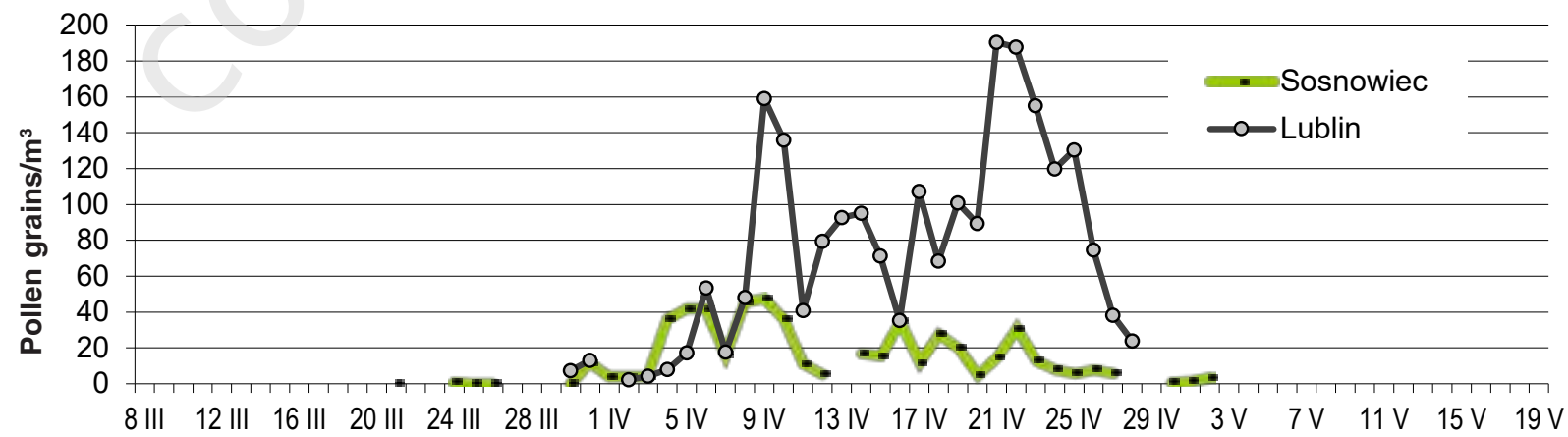

Figure 3. Yew and juniper pollen count in Olsztyn and Opole in 2019.

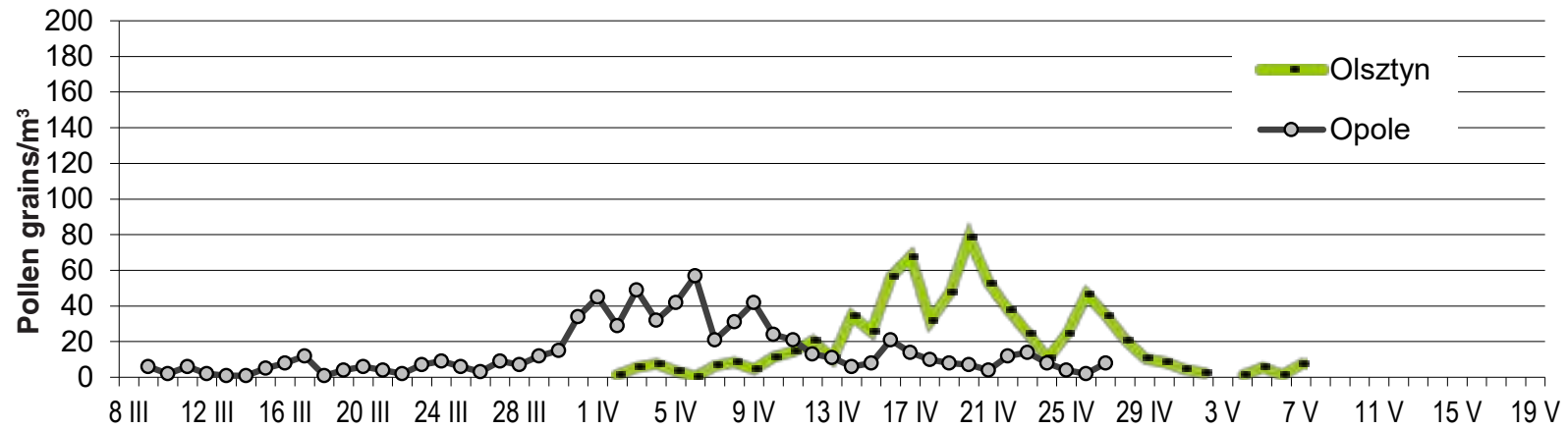


Figure 4. Yew and juniper pollen count in Szczecin and Piotrkow Trybunalski in 2019.

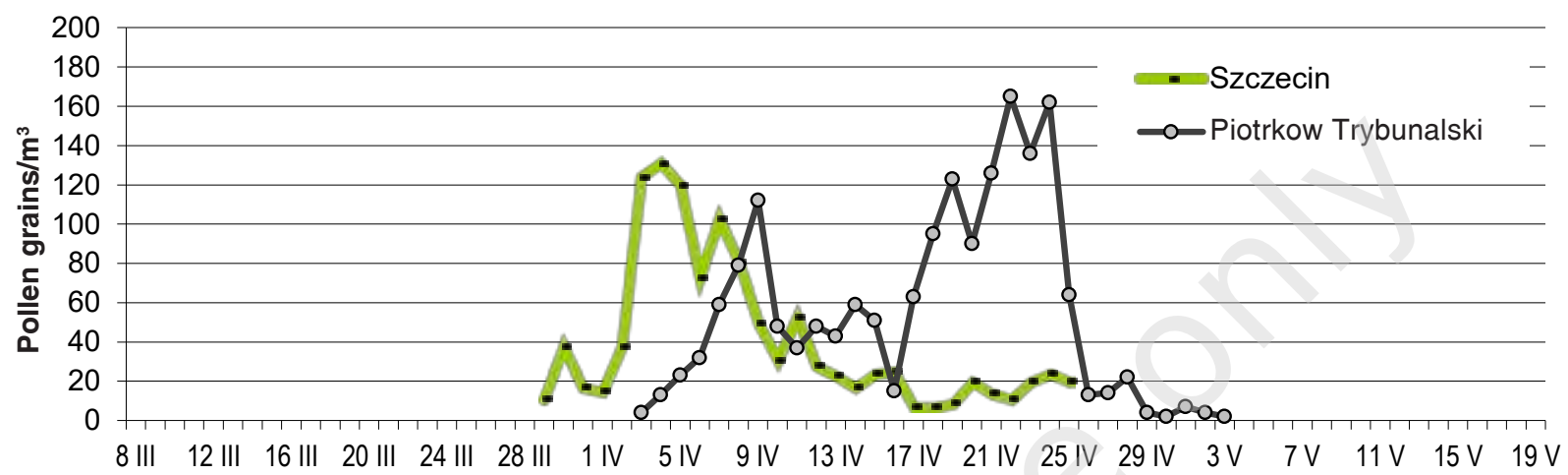

Figure 5. Ash pollen count in Warsaw in 2019.

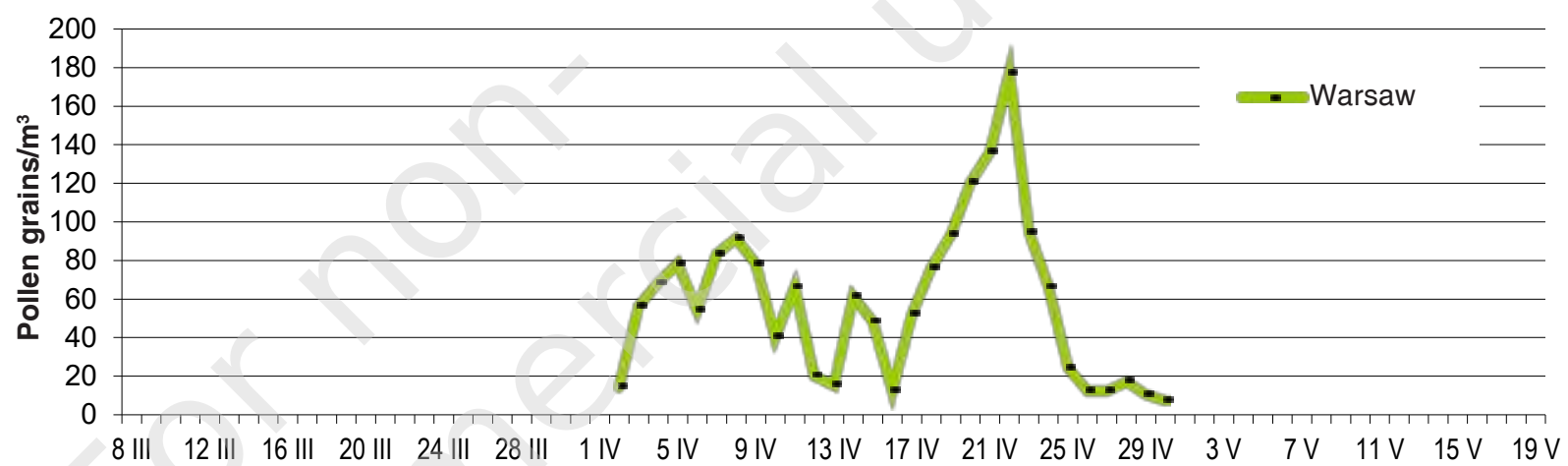

at the beginning of March [12], on average, one week earlier than in 2019 (tab. 1, figs 1-5). Comparison of the onset of pollen season in Polish cities in 2008 [13] and 2019 showed almost identical dates for the beginning of the pollen season in those years, while in 2008 significantly higher SPI values were recorded than in 2019 , in this paper (the lowest SPI in 2008 was 980 and in $2019-285$ ).

The highest daily pollen count of ash was noted in 2019 in Lublin on April 21 ${ }^{\text {st }}$ (190 grains/m³) (tab. 1, fig. 2) and the highest annual sum of Fraxinus pollen grains (SPI) was observed also in Lublin; in other cities SPI value was much lower (the lowest value in Bialystok SPI - 285). In 2008 [13] the maximum daily concentration was observed April $15^{\text {th }}$ in Lublin (like in 2019), and in 2017 [12] - April $2^{\text {nd }}$ in Cracow. The highest SPI value both in 2008 and in 2017 was noted also in Cracow.

However, the highest ash pollen allergen hazard occurred (above 150 grains $/ \mathrm{m}^{3}$ ) in Lublin -5 days. In other cities that value ranged from 0 to 2 days. The comparison of these taxa's pollen seasons in previous years revealed that in 2008 [13] pollen concentrations were similar to 2019, while in 2017 [12] pollen allergen hazard was much lower than in 2019.
In light of these rising numbers of allergic diseases, the consideration of allergy-friendliness in urban green planning seems to be essential. When related to pollen allergies, however, it can also be considered as an ecosystem disservice representing a conflict to other ecosystem services such as recreation and health benefits as green spaces regulate climate and improve air quality. Urban green planning mainly focusses on specific site requirements (e.g. temperature tolerance, pest resistance, tolerance to pruning) and aesthetics as crucial criteria in the choice of plants. The allergenic potential of plants, however, is often neglected. Still, more research is required regarding the use of allergenic plants in green spaces and the development of allergy-friendly green areas in urban environments. Some attempts have been made to formulate planning recommendations to reduce negative health impacts caused by plants producing allergenic pollen [14]. For example, it was recommended to develop gardens with only female plants or with a great diversity of non-allergenic plants [15]. The allergenic potential of plants was assessed by Thomas L. Ogren [15] who developed the Ogren Plant Allergy Scale (OPALS - a plant-allergy ranking system used by the United States Department of Agriculture). The scale categorises species at 
ten levels with 1 being non-allergenic and 10 being highly allergenic. European ash (Fraxinus excelsior) is often utilised as a landscape tree and is commonly found in gardens and parks (high concentrations of Fraxinus pollen are also recorded in Polish cities, which is confirmed by this work). Ash tree in OPALS reaches 6 (moderate potential to cause allergic reactions, exacerbated by over-use of the same plant throughout a garden), while birch pollen in this scale rating 9 (extremely high potential to cause allergic reactions, should be replaced with less allergenic species).

\section{Conclusions}

Fraxinus pollen grains are present in the air of Polish cities usually in April and at the beginning of May.

Ash pollen season in most cities was above 30-40 days long (only in Bialystok and Opole 50 days) and was characterized by extremely different total annual pollen SPI (from 285 in Bialystok to 2207 in Lublin).

The start of Fraxinus pollen season in 2019 occurred in the end of March or in the beginning of April and ended at the turn of April and May.

The highest ash pollen allergen hazard occurred in 2019 in Lublin, Warsaw, Piotrkow Trybunalski and Bydgoszcz. The number of days with concentrations above the established threshold was very different in individual cities and the highest in Lublin.

The highest variability in the analysed seasons was found in the peak value and annual total, while the lowest in the end of the season.

\section{References}

1. Vara A, Fernández-Gonzáleza M, Airab MJ et al. Fraxinus pollen and allergen concentrations in Ourense (South-western Europe). Environ Res 2016, 147: 241-248.

2. APG II system. An update of the angiosperm phylogeny group classification for the orders and families of flowering plants: APG II. Bot J Linn Soc 2003, 141(4): 135-140.

3. Ralska-Jasiewiczowa M, Latałowa M, Wasylikowa $K$ et al (eds). Late Glacial and Holocene history of vegetation in Poland based on isopollen maps. Polish Academy of Sciences, Cracow 2004.

4. Silva Palacios I, Tormo Molina R, Munoz Rodriguez AF. The importance of interactions between meteorological conditions when interpreting their effect on the dispersal for pollen from homogeneously distributed sources. Aerobiologia 2007, 23: 17-26.
5. Jianan X, Zhiyun O, Hua Z et al. Allergenic pollen plants and their influential factors in urban areas. Acta Ecologica Sinica 2007, 27(9): 3820-3827.

6. Mandrioli P, Comtois P, Dominguez E et al. Sampling: Principles and Techniques. In: Mandrioli P, Comtois P, Levizzani V (eds). Methods in Aerobiology. Pitagora Editrice Bologna. Bologna 1998, 47-112.

7. Emberlin $J$, Savage $M$, Woodman $R$. Annual variations in the concentrations of Betula pollen in the London area 1961-1990. Grana 1993, 32: 359-363. DOI: 10.1080/00173139309428965.

8. Lipiec A, Weryszko-Chmielewska E, Piotrowska K et al. Analiza stężenia pytku jesionu w wybranych miastach Polski w 2007 r. Alergoprofil 2007, 3(3): 50-54.

9. Rapiejko P. Alergeny pyłku jesionu. Alergoprofil 2008, 4(1): 46-48.

10. Steinman H. Tree pollens. Allergy - Which allergens? Allergy Resources International. Sweden 2008: 188.

11. Hemmer W, Focke M, Wantke F et al. Ash (Fraxinus excelsior) - pollen allergy in central Europe: Specific role of pollen panallergens and the major allergen of ash pollen, Fra e 1. Allergy 2000, 55: 923-930.

12. Szczygielski K, Puc M, Stacewicz A et al. Ash pollen count in the air of selected Polish cities in 2017. Alergoprofil 2017, 13(2): 85-90.

13. Puc M, Rapiejko P, Myszkowska D et al. Pytek jesionu w powietrzu wybranych miast Polski w roku 2008. Alergoprofil 2008, 4(3): 35-39.

14. Jochner-Oette S, Stitz T, Jetschni J et al. The Influence of Individual-Specific Plant Parameters and Species Composition on the Allergenic Potential of Urban Green Spaces. Forests 2018, 9: 284. DOI: 10.3390/f9060284.

15. Ogren T. The Allergy-Fighting Garden. Ten Speed Press. Berkeley, CA 2015: 205.

ORCID

M. Puc - ID - orcid.org/0000-0001-6734-9352

D. Kotrych - ID - orcid.org/0000-0003-4221-2944

A. Lipiec - ID - orcid.org/0000-0003-3037-2326

D. Jurkiewicz - ID - orcid.org/0000-0003-3729-2679

E. Kalinowska - ID - orcid.org/ 0000-0003-4821-6882

K. Piotrowska-Weryszko - ID - orcid.org/ 0000-0003-3827-3218

P. Rapiejko - ID - orcid.org/ 0000-0003-3868-0294

Z. Siergiejko - ID - orcid.org/ 0000-0002-3876-5135

\section{Authors' contributions:}

Work input: A - work concept, B - aerobiological data, C - literature review, D - writing the thesis, E- work correction.

Puc M.: A, B, C, D, E; Kotrych D.: B, C; Lipiec A.: B, C; Chłopek K.: B; Jurkiewicz D.: B; Kalinowska E.: B; Piotrowska-Weryszko K.: B; Rapiejko P.: B; Siergiejko Z.: B. Conflict of interests: The authors declare that they have no competing interests. Ethics: The contents presented in this paper are compatible with the rules the Declaration of Helsinki, EU directives and standardized requirements for medical journals.

Financial support: Research in Bialystok, Bydgoszcz, Sosnowiec, Piotrkow Trybunalski, Opole, OIsztyn and Warsaw funded by Allergen Research Center Ltd. 


\section{ORIEINAL PAPER}

Corresponding author:

Małgorzata Puc, Assoc. Prof.

Faculty of Physical, Mathematical and Natural Sciences,

University of Szczecin

71-412 Szczecin, Felczaka 3c

e-mail: malgorzata.puc@usz.edu.pl

(c) Medical Education. For private and non-commercial use only. Downloaded from https://www.journalsmededu.pl/index.php/alergoprofil: 26.04.2023; 04:13,56 